Gazi University
Journal of Science
http://dergipark.gov.tr/gujs

\title{
The Related Study Tendencies in the Field of Gasification: A Bibliometric Approach
}

\author{
Sertac Samed SEYITOGLU (D), Ali KILICARSLAN* (D) \\ Hitit University Faculty of Engineering, Department of Mechanical Engineering, 19030, ÇORUM
}

\author{
Highlights \\ - The coal gasification related to both bibliometric and historical analyses have investigated. \\ - The number of coal gasification publications have especially increased after 2005. \\ - In total, 3413 publication have been found in the subject of coal gasification.
}

\begin{tabular}{l} 
Article Info \\
\hline \\
Received: 11 Feb 2021 \\
Accepted: 13 Sep 2021 \\
Keywords \\
\hline Gasification \\
Coal gasification \\
Bibliometric analysis \\
WOS \\
Bibexcel
\end{tabular}

\begin{abstract}
Undoubtedly, energy plays a vital role in every sphere of life. Fossil energy sources such as coal and natural gas are generally used for energy production. People are looking for more efficient use of the source in recent years due to the rapid depletion in the fossil fuel resources. Gasification of coal is a useful method for produce clean and efficient energy. This study was carried out to find out the various trends in scientific studies that provide literature for the field of coal gasification on world. All data used in this study have been reached from Web of Science database. In this study, the coal gasification related to both bibliometric and historical analyses were investigated. The Web of Science database was scanned for the articles about coal gasification between the years of 1989 and 2020. The considered parameters in the bibliometric analysis are the number of citations and documents, authorships and ownerships, patterns of international collaborations and addresses.
\end{abstract}

\section{INTRODUCTION}

Nowadays, the world population is increasing rapidly and consequently industrialization is increasing in a significant way. As a result, there is an increase in energy consumption. More than half of the world's energy production is provided by using fossil sources [1,2]. Considering the harmful effects of the fossil fuels and the possibility of exhaustion, it is very important to be able to use those resources more efficiently [3-7].

Coal is the oldest known fossil fuel all around the world. It is an important source of energy because of its low costs at an acceptable level. Moreover, coal is abundant and omnipresent [8-13]. Generally, coal is burned to produce energy at thermal plants. Therefore, the use of coal causes greenhouse effect such as $\mathrm{So}_{\mathrm{x}}$, $\mathrm{NO}_{\mathrm{x}}, \mathrm{CO}_{\mathrm{x}}$ gases [14-18]. One of the ways of using coal more efficiently is to convert the coal into gas [1922]. Gasification technology was widely used in European countries in the 1940s when oil was insufficient. Then, the coal gasification plants were developed and coal gasification systems have reached today. Gasification is a chemical transformation that solid fuel is converted to gas by using high temperature, high pressure and oxygen [23-28]. The coal gasification reaction is endothermic and the working temperature is higher than $700 \mathrm{C}^{\circ}$. Gasification process also generates less greenhouse effect [29-31]. Therefore, the gasification technology is promising for future $[32,33]$. The composition and the amount of syngas depend on the coal type, oxidant type, gasifier temperature, residence time and the gasification methods [34]. Syngas contains various gases, such as $\mathrm{CO}, \mathrm{CO}_{2}, \mathrm{H}_{2}, \mathrm{CH}_{4}$.. etc. [35]. Electricity, heat, hydrogen and various synthetic fuels can be produced thanks to the syngas [36-38]. 
The integrated gasification combined cycle (IGCC) system is more effective than general combustion systems [39]. The IGCC produces power from coal. The coal is converted into syngas in the gasifier. The syngas which is produced after the gasification of coal is sent to the combined power systems that are called gas turbine and steam turbine systems. As a result, the electricity is produced [40-43]. Hydrogen can also be produced with integrated systems that are applied to coal gasification systems [44-50]. Additionally, synthetic fuels can be produced [51-57].

The literature of coal gasification has grown substantially thanks to the advancement of the gasification technology. Coal gasification systems have drawn the attention of researchers because of their advantages. It is very important to analyze the studies in any discipline according to the periods. This investigation indicates the position of the subject in the science. One of the most important ways of achieving that is the bibliometric analysis. The application of mathematical and statistical methods to books and other communication is called bibliometry [58,59]. Bibliometric analyses may describe illustrative (such as the number of articles published in a given year) or evaluative (such as citation analysis) [60] aspects of the literature. Statistical investigation of data such as author, subject, cited author, and cited sources is possible thanks to the bibliometric analysis [61].

Table 1. Bibliometric studies in the field of Engineering and Energy

\begin{tabular}{|l|l|l|l|}
\hline Authors & Database & Descriptions & Timeframe \\
\hline Ma et al. [62] & WoS & $\begin{array}{l}\text { Understanding for a potential direction of microalga- } \\
\text { derived biodiesel }\end{array}$ & $1993-2016$ \\
\hline Zhang et al. [63] & WoS & Tendencies of the global biodiesel & $1991-2015$ \\
\hline Li et al. [64] & WoS & The research trends in Solid waste reuse and recycling & $1992-2016$ \\
\hline Tian et al. [65] & WoS & $\begin{array}{l}\text { The characteristics of carbon emissions research in the } \\
\text { transportation sector }\end{array}$ & $1997-2016$ \\
\hline Park and Nagy [66] & WoS & $\begin{array}{l}\text { Investigate the interaction between thermal comfort and } \\
\text { building control research. }\end{array}$ & $1970-2016$ \\
\hline Imran et al. [67] & Scopus & The research in the field of the organic Rankine cycle & $2000-2016$ \\
\hline Chen et al. [68] & WoS & A comprehensive analysis of emergy related literatures & $1999-2014$ \\
\hline Wang and Li [69] & WoS & The development trends in shale gas research. & $1990-2014$ \\
\hline Zhang et al. [70] & WoS & The research in the field of Water Footprint & $2006-2015$ \\
\hline Wang et al. [71] & Scopus & investigated the characteristics of the low carbon & $1995-2014$ \\
\hline Geng et al. [72] & Scopus & $\begin{array}{l}\text { Investigated residential energy and greenhouse gas } \\
\text { emission related researches }\end{array}$ & $1996-2016$ \\
\hline Feng et al. [73] & Scopus & $\begin{array}{l}\text { The research in the field of corporate social responsibility } \\
\text { in supply chain management }\end{array}$ & $1997-2017$ \\
\hline Zeng and Chini [74] & WoS & The research on the embodied energy of buildings. & $1996-2015$ \\
\hline Grando et al. [75] & WoS & The research on biogas production & $1990-2015$ \\
\hline Jiang et al. [76] & WoS & Bibliometric exploration of hydropower research & $1994-2013$ \\
\hline Chen et al. [77] & WoS & The examine Chinese energy and fuels research & $1993-2012$ \\
\hline Zhang and Liang [78] & WoS & The research in the field of emission reduction & $1992-2019$ \\
\hline Li et al. [79] & WoS & The research on the carbon footprint of higher education & $2010-2019$ \\
\hline Kasavan et al. [80] & WoS & Tendencies of the plastic pollution in the water ecosystem & $2000-2020$ \\
\hline
\end{tabular}

The aim of the bibliometric analysis is to measure science globally. The bibliometric analysis involves different disciplines such as social, physical and health science. Therefore, it is important to choose any discipline for the analysis. There are three laws such as Zipf, Bradford and Lotka on basis of bibliometric analysis [81-84]. The Zipf's law is related the frequency distributions of the words. Bradford's law is used to determine the number of main journals in a known area. Lotka's law evaluates the performance of the authors in a known area. Bibliometric analysis has two main steps such as performance analysis and mapping. Firstly, the data is collected and then it is classified according to author names, affiliation, years, document type, country, citations and institutions. Secondly, maps are made of using classified data thanks to the different ways such as co-citation and co-word analysis $[85,86]$. There are widely used sources for bibliometric analysis such as Web of Science, Google Scholar and Scopus [87]. The data received from the sources is arranged and mapped by using different softwares such as bibexcel, vosviewer, pajek, Excel, 
SSPS and Gephi $[65,88,89]$. Although the bibliometric analysis is generally used in the social sciences, it has also been used in the engineering sciences recently. Table 1 presents the bibliometric study in the field of engineering in the last decade.

The main objective of this study is to inspect the research activities within the coal gasification at the global level in the period between 1989 and 2020. There is no article that uses bibliometric analysis and mapping to summarize scientific developments on this topic in the existing literature. Therefore, in this study, we propose a bibliometric approach for the review of coal gasification at the literature. This paper has four sections. Section 2 presents bibliometric methods, scientific approach and the data where and how it is taken. The results and discussions are given in section 3 and finally, section 4 presents the conclusion remarks.

\section{BIBLIOMETRIC ANALYSIS}

This study was carried out to ascertain the assorted trends in studies in the field of coal gasification. All data used in this study was taken from Web of Science database. This study answers some questions such as "What is the number of publications on coal gasification?", "Who are the most productive authors?", "What are the most productive countries?", "How is the distribution of document type of studies?", "What are the most popular journals about coal gasification?", "What are the leading keywords?" etc.

The researchers should know some limitations about bibliometric analysis. One of them, the bibliometric analysis may not show that a publication is always a good quality publication, which means the number of citation of a publication does not mean that a paper is at a high quality. The other one, all research areas and all publications may not be included in the bibliometric databases. For that reason, time is required for a comprehensive citation analysis [90].

Bibexcel software which was developed by Persson is used to carry out the bibliometric analysis [91]. Bibexcel is commonly used as a tool for helping the bibliometric analysis. That software arranges the data taken from Web of Science or Scopus. Afterwards, the data is used for mapping.

The data to be used in this study was taken from Web of Science database according to "coal gasification" keyword, considering the period 1989-2020. Web of Science is the most widely accepted and frequently used database for the analysis of scientific publications [92-95]. There are several sub databases in Web of Science. For instance, Science Citation Index Expanded (SCI-E), Social Sciences Citation Index (SSCI), Arts \& Humanities Citation Index (A\&HCI), Emerging Sources Citation Index (ESCI), Conference Proceedings Citation Index- Science (CPCI-S) and Conference Proceedings Citation Index Social Science \& Humanities (CPCI-SSH). SCI-E, SSCI, CPCI-S and CPCI-SSH indexes are preferred in this study.

\section{RESULTS AND DISCUSSION}

The data used in this study was obtained from Web of Science database by using keyword "coal gasification". The research area was limited to thermodynamics, engineering, energy fuels and chemistry. The publications were downloaded in the bibliographic style that is called plain text of Web of Science with information in title, authors, country, keywords etc. Then, "Plain Text" was imported to BibExcel software. BibExcel was used for the general statistical information of publications. As a result, the number of publications is determined as "3413" at the Web of Science between the years of 1989 and 2020. The data was extracted in August 2021. The timeline of the coal gasification publications from 1989 to 2020 is shown in Figure 1. In addition, Figure 2 shows the number of published document type according to published years. 


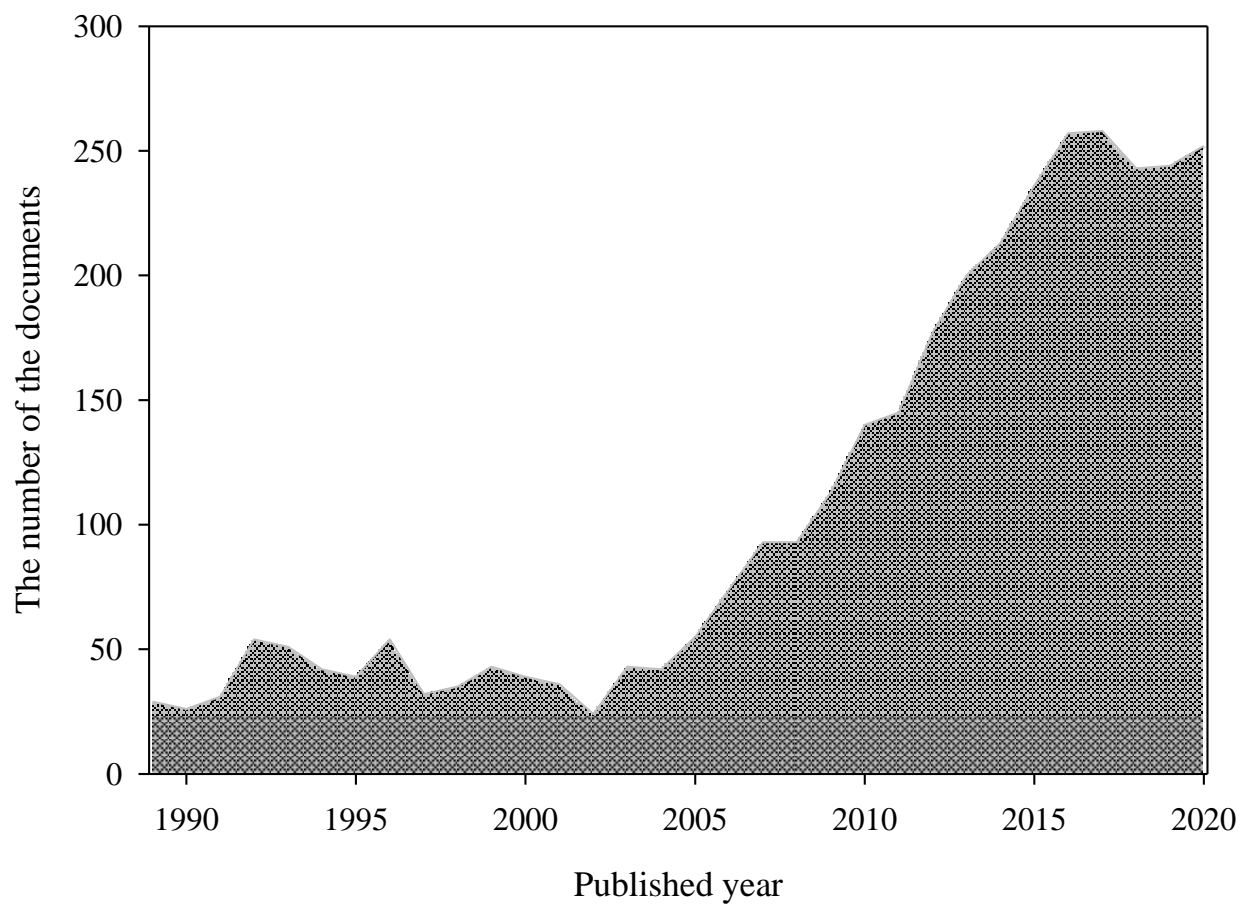

Figure 1. Trends in Coal Gasification publications (1989-2020)
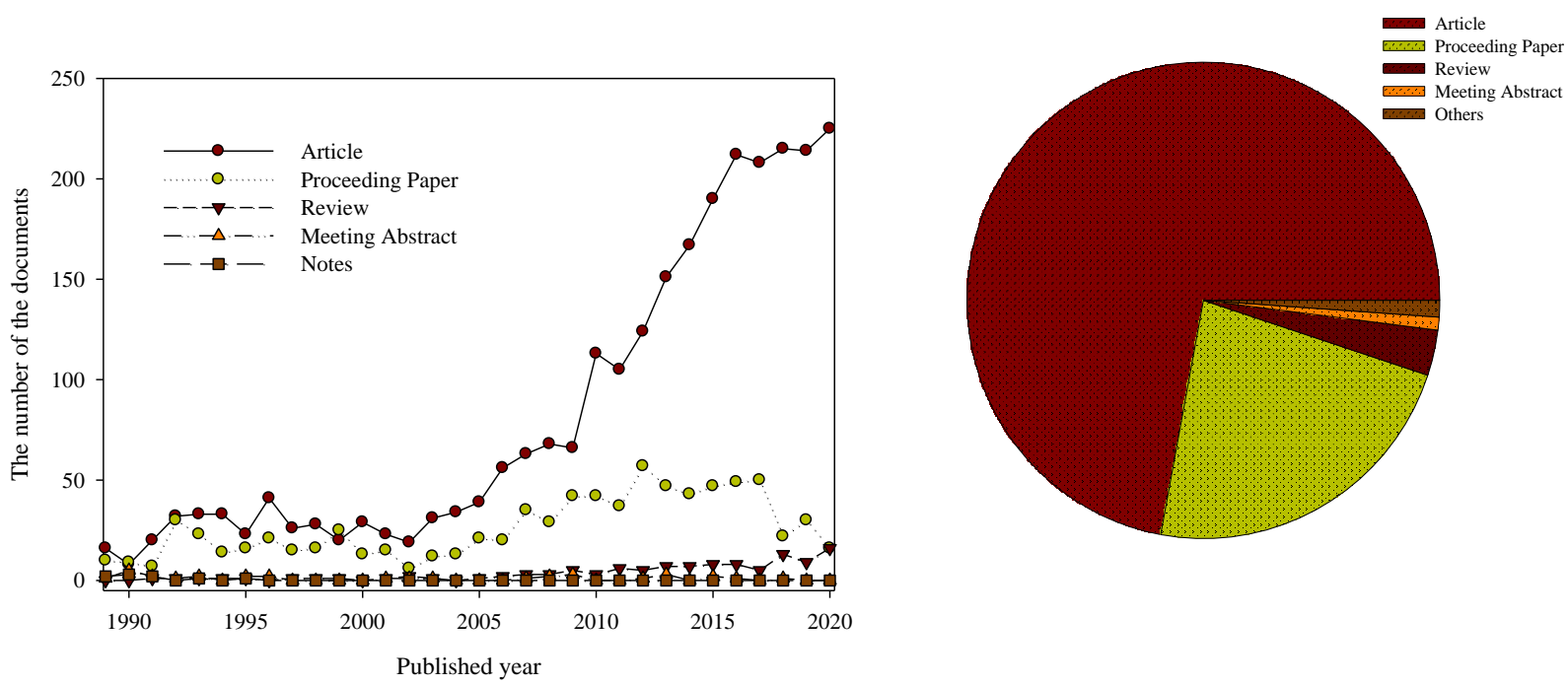

Figure 2. Number of published document types on coal gasification between 1989 and 2020

Figure 1 depicts the change of the number of publications with respect to the published year. The number of coal gasification publications increased from only 29 in 1989 to 252 in 2020 . Especially, the publication rates have considerably increased since 2005 . The results show that the topic presents a rising trend. This result can be explained by increasing energy requirement, decreasing greenhouse effect and increasing need of using coal more effectively. There are 12 document types in the database. Articles are the dominant document comprising 2632 of the total. The remaining publications are conference proceeding papers (832), reviews (112), meeting abstract (33), news item (17), editorial materials (15), note (9), letter (7), correction (2) and retracted publications (2). Figure 2 shows the number of published document type with respect to the published year and the distribution of the document type. In addition, the dominant language for publications in coal gasification is English $(96.52 \%)$ which is followed by Polish (1.137\%), Japanese $(0.891 \%)$, German $(0.769 \%)$ and Chinese $(0.154 \%)$. 
Table 2. Top 5 productive journals in the coal gasification field from 1989 to 2020

\begin{tabular}{|l|l|l|l|l|l|}
\hline Journal & Amount & Percentage & h-index & Avr. citiation per item & IF (2020) \\
\hline Fuel & 331 & $9.69 \%$ & 56 & 33.12 & 5.578 \\
\hline Energy \& Fuels & 199 & $5.82 \%$ & 41 & 25.22 & 3.421 \\
\hline Int. J. of Hydrogen Energy & 191 & $5.59 \%$ & 40 & 31.79 & 4.939 \\
\hline Fuel Processing Tech. & 122 & $3.57 \%$ & 30 & 26.56 & 4.982 \\
\hline Energy & 117 & $3.42 \%$ & 32 & 27.68 & 6.082 \\
\hline
\end{tabular}

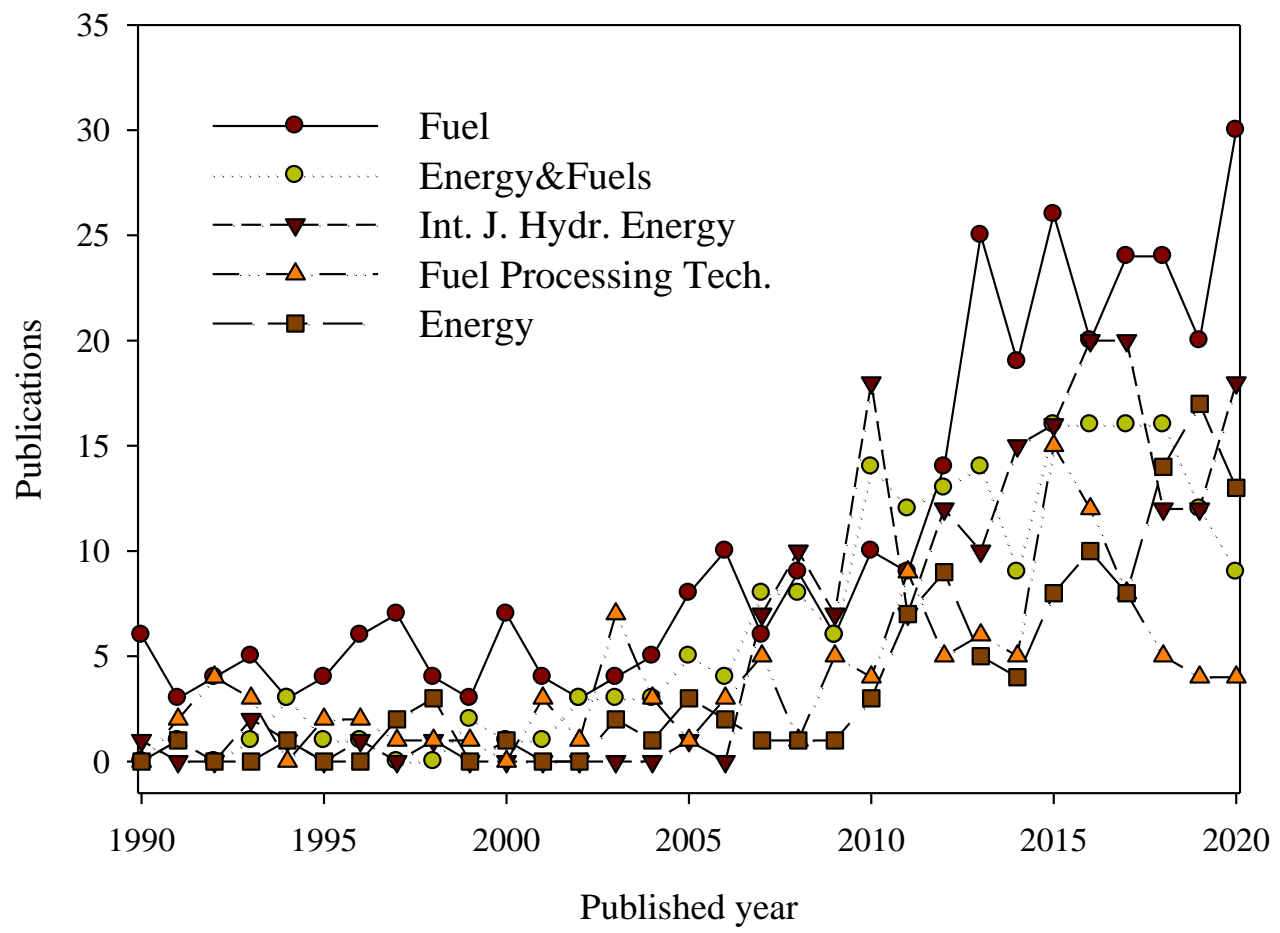

Figure 3. Timeline of coal gasification publications of the most productive journals between 1989 and 2020

Table 2 presents the top five most productive journals based on publications including the number of papers, h-index, average citation per items and impact factor (IF). Fuel journal that has an impact factor of 5.578 and an h-index of 56 is the most preferred journal and accounts for $9.69 \%$ of the total coal gasification publications from 1989 to 2020 . Fuel journal ranking the first place by the number of articles among all related journals has the second highest impact factor and its h-index is also first highest among those five journals. It results that the Fuel journal is a journal with a large influence on the coal gasification research. The average number of articles on the subject of coal gasification that are published in Fuel journal is 10.6 papers per year. This is followed by Energy\&Fuels (6.41 papers per year) and International Journal of Hydrogen Energy (6.16 papers per year). The top five journals account for $28.09 \%$ of the coal gasification publications. Fuel, Energy\&Fuels, International Journal of Hydrogen Energy, Fuel Processing Technology and Energy journals have more than 100 publications and impact factor of higher than 3. Figure 3 presents the timeline of the publications in the Top 5 journals based on published years. 
Table 3. Top 10 productive countries in the coal gasification field from 1989 to 2020

\begin{tabular}{|l|l|l|l|l|l|l|}
\hline Country & $\begin{array}{l}\text { Total } \\
\text { Publication }\end{array}$ & Citation & $\begin{array}{l}\text { Ave citations } \\
\text { per item }\end{array}$ & $\begin{array}{l}\text { Citations } \\
\text { per year }\end{array}$ & $\begin{array}{l}\text { Per. of publications of a } \\
\text { country }\end{array}$ & h-index \\
\hline China & 1166 & 19981 & 17.14 & 644.5 & $28.76 \%$ & 60 \\
\hline USA & 478 & 12397 & 25.94 & 399.9 & $18.69 \%$ & 58 \\
\hline Japan & 268 & 4883 & 18.22 & 157.5 & $7.03 \%$ & 35 \\
\hline Canada & 177 & 5340 & 30.17 & 172.2 & $7.68 \%$ & 39 \\
\hline Poland & 168 & 2045 & 12.17 & 65.9 & $2.94 \%$ & 23 \\
\hline South Korea & 144 & 2404 & 16.69 & 77.5 & $3.46 \%$ & 26 \\
\hline Germany & 142 & 3891 & 27.4 & 125.5 & $5.60 \%$ & 29 \\
\hline India & 140 & 2343 & 16.74 & 75.5 & $3.37 \%$ & 25 \\
\hline Australia & 138 & 4766 & 34.54 & 153.7 & $6.86 \%$ & 41 \\
\hline England & 120 & 3273 & 27.28 & 105.5 & $4.71 \%$ & 33 \\
\hline
\end{tabular}

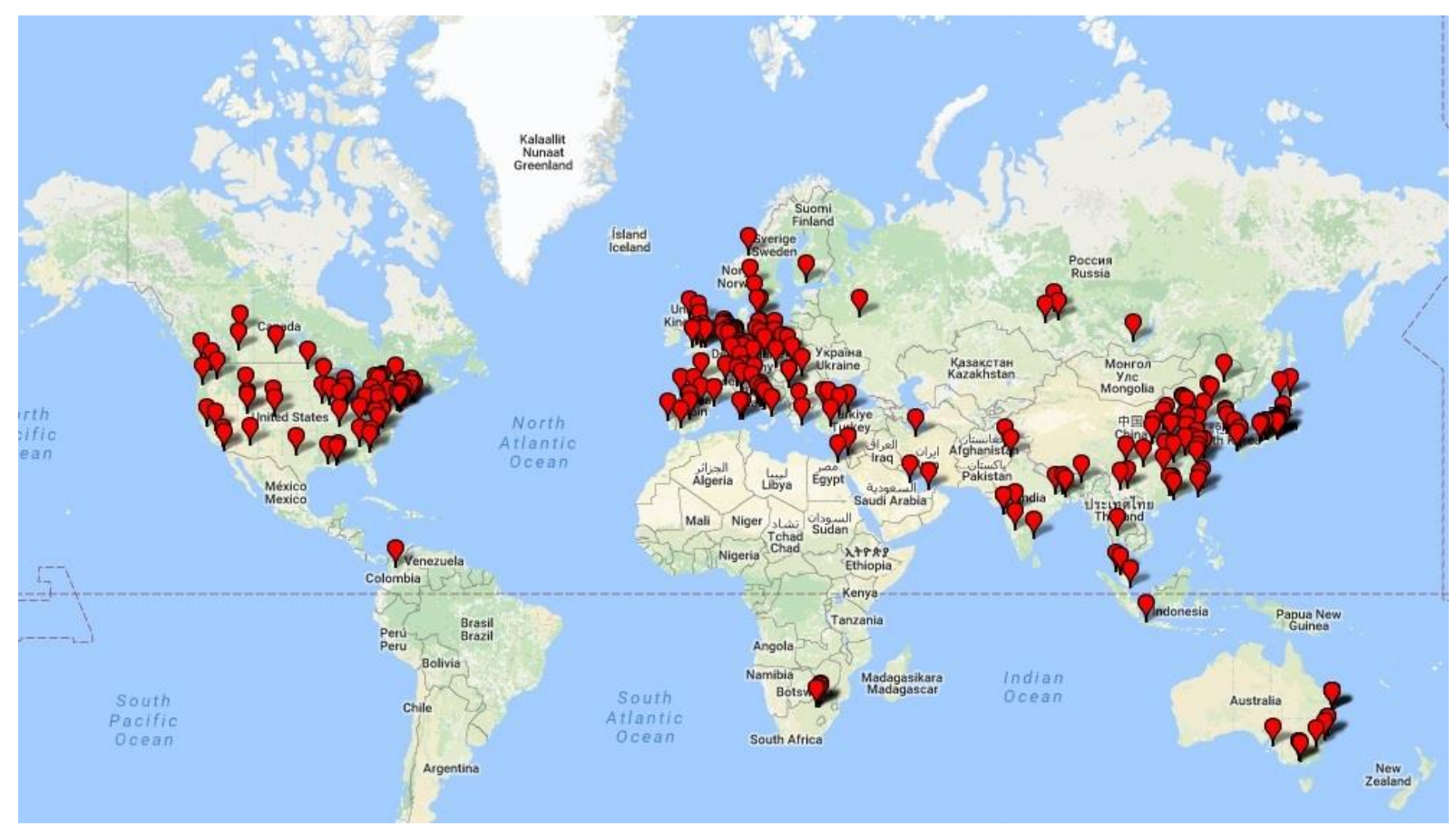

Figure 4. The global distribution of coal gasification publications

Figure 4 presents the global distributions of coal gasification publication from 1989 to 2020 . The Top 10 productive countries are ranked with respect to the number of publications in Table 3 . The table also shows the citation rate, average citations per items rate, citations per year rate, the percentage of publications of a country rate and h-index. The Top 10 countries which published about $86.17 \%$ of the publications are four Asia countries, two North America countries, three Europa countries and one Oceania country. China which has 1166 publications is the most productive country and accounts for $34.16 \%$ of the total coal gasification publications from 1989 to 2020 . China is developing rapidly and has increasing need for the energy. In addition, the main energy source of China is coal $[96,97]$. Therefore, the result can be expected. The second most productive country is USA (478 publications) which is followed by Japan (268 publications), Canada (177 publications) and Poland (168 publications) respectively. Australia has the highest average citations per items among other countries. 


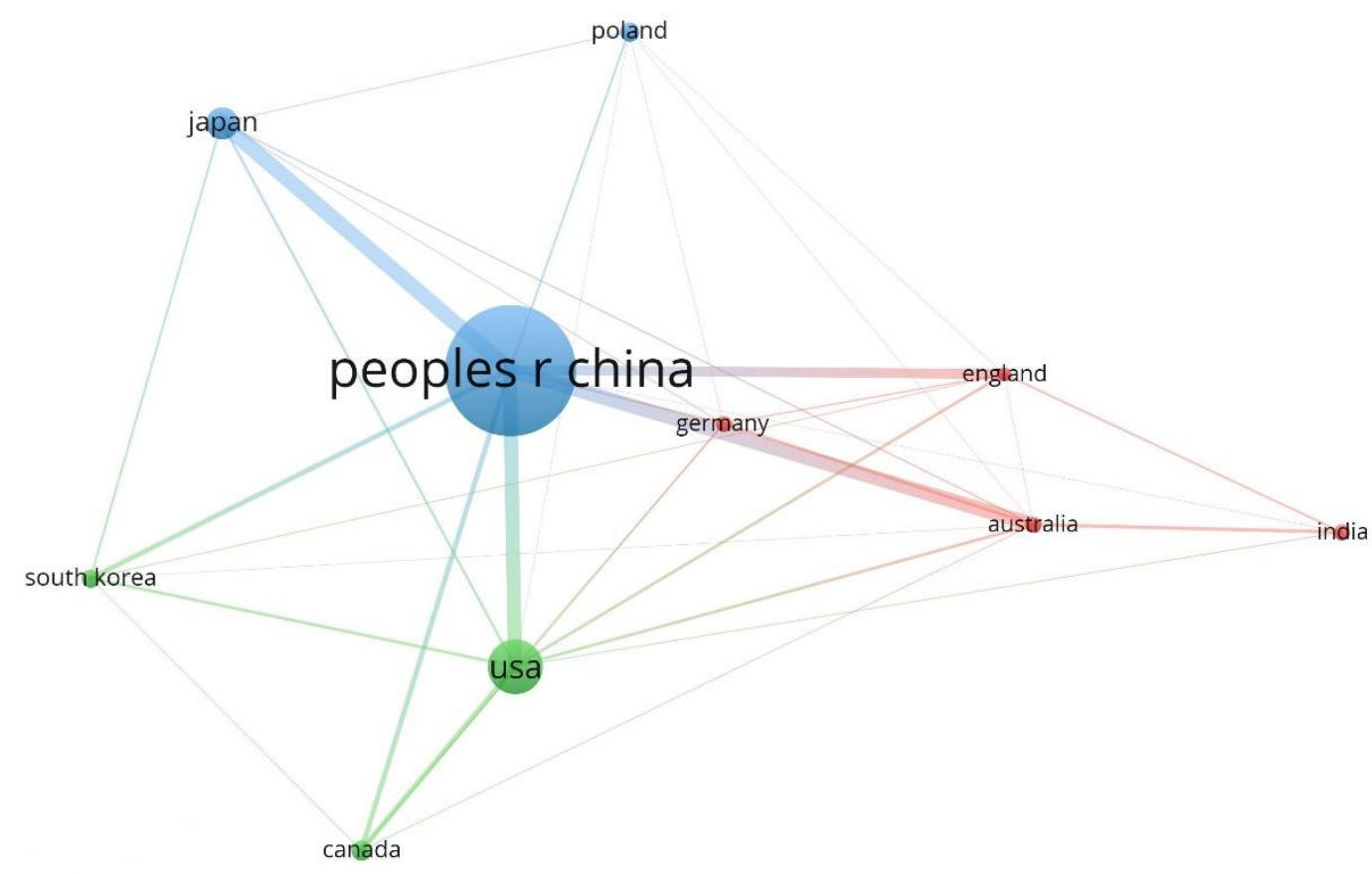

Figure 5. The cooperation network of the top 10 productive countries

Figure 5 shows the cooperative relationships among the top ten productive countries in the field of coal gasification research by using social network analysis. The size of the circles is related to the number of the publications while the thickness of the lines between circles shows the frequency of cooperation between two countries. China and USA are most productive countries and those countries are also the most cooperating countries in the network, followed by Japan-China and China-England respectively. China, USA and Australia are in the cooperation with all top 10 productive countries. Those are followed by England and Germany. In addition, India is the least cooperative country among all top productive countries. 


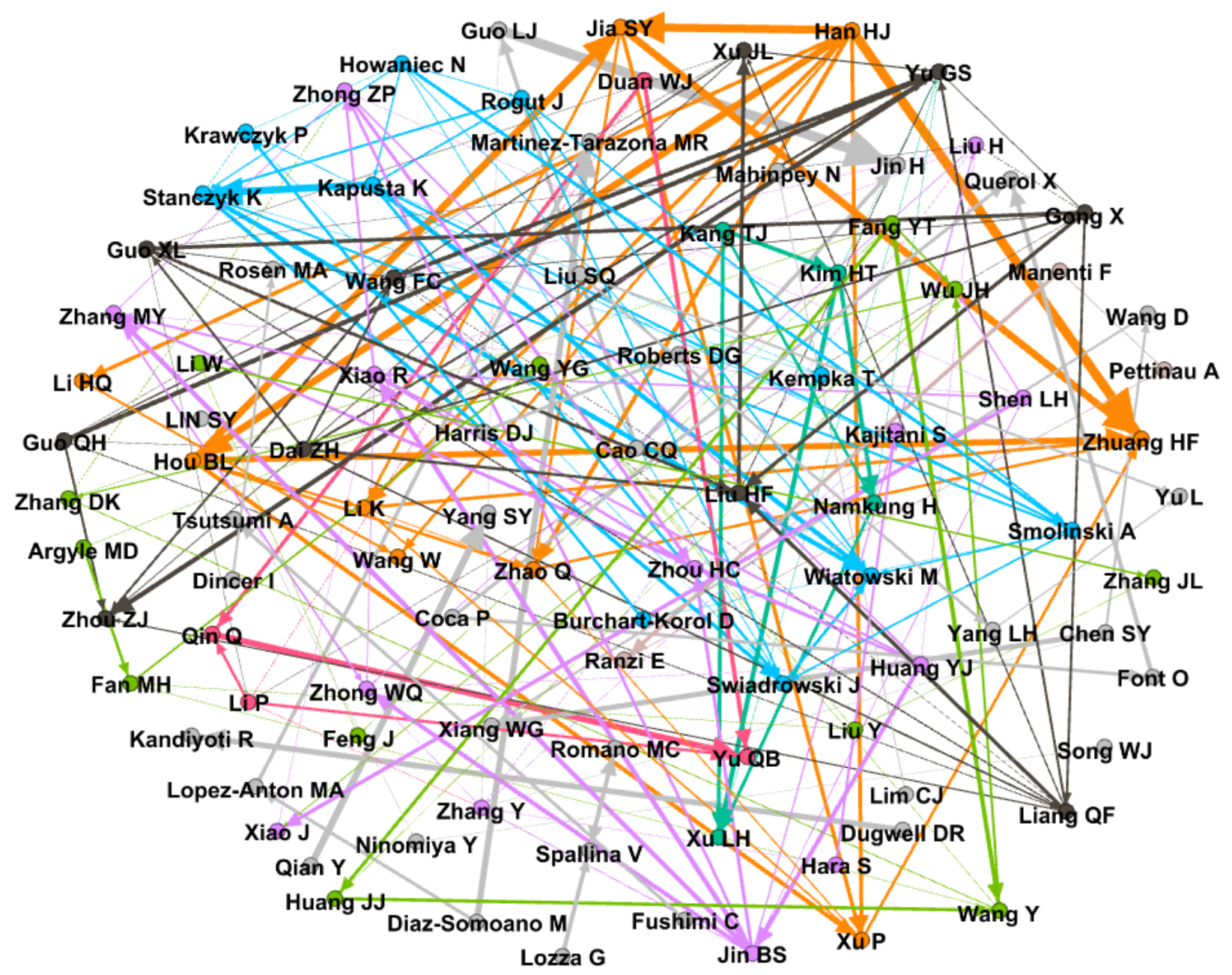

Figure 6. The cooperation network of the authors

Totally, 7067 authors have contributed to the field of coal gasification. The most productive author is Han HJ with 50 publications from China. The authors list includes more authors from China. The author cooperation is shown in Figure 6. In Figure 6, each author is presented as a circle and the size of circles is proportional to the number of the collaboration. The thickness and number of the lines between the authors show the strength of collaboration in the field. According to Figure 6, the most collaborative authors are from China, followed by authors from USA. 


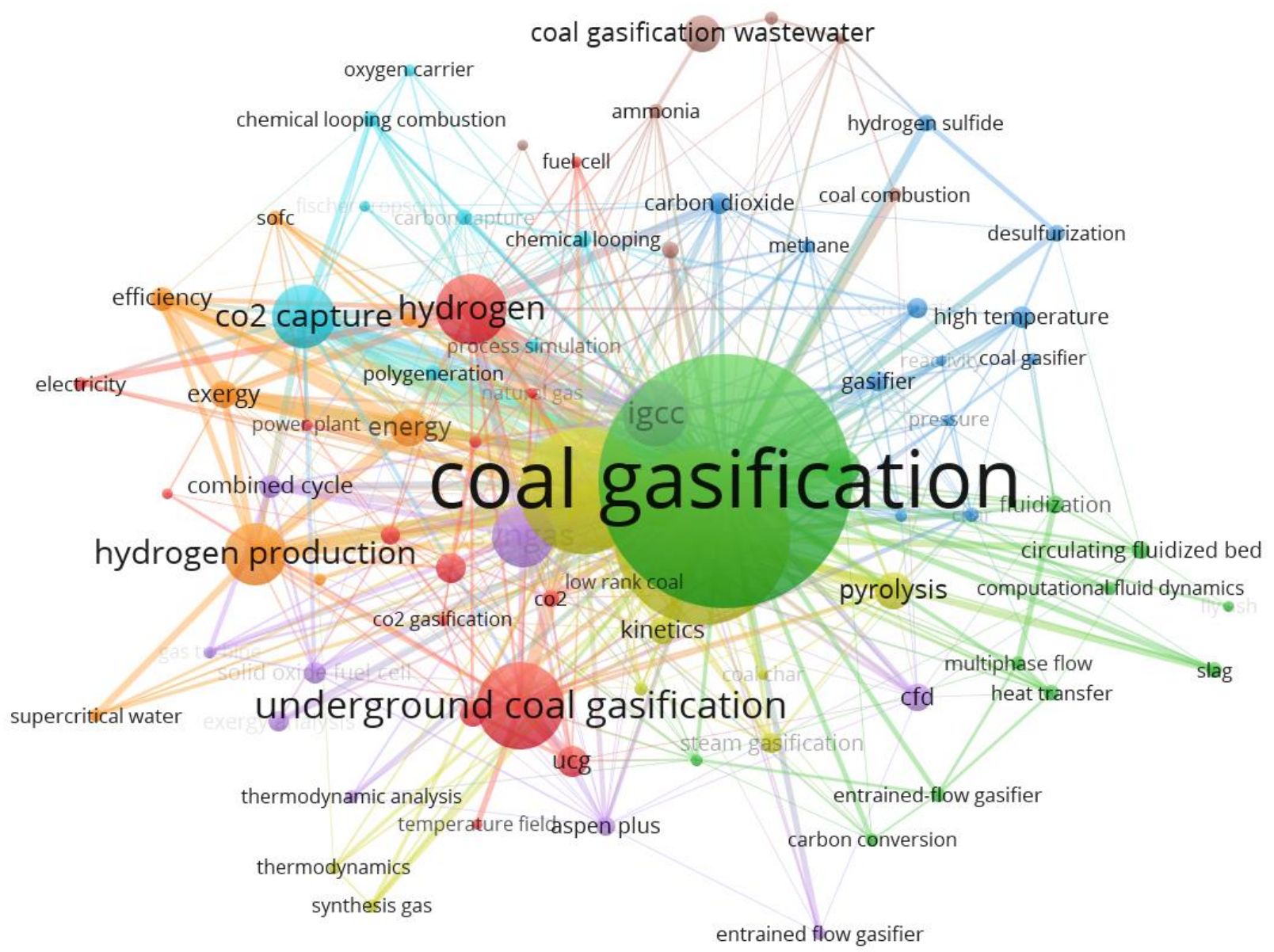

Figure 7. Co-word network map of author keywords

The top keywords used (ten times or more) in the publications are shown in Figure 7. Co-occurrence of author keywords of articles was analyzed. The irrelevant words were ignored in this analysis such as modelling, catalyst, ccs, calcium, mathematical modelling, phenol and trace elements. The most frequently used keyword was "coal gasification" among 5045 keywords. The next most frequently used keyword was "gasification", followed by "coal" and "underground coal gasification" respectively. The keywords that are $\mathrm{CO}_{2}$ capture, hydrogen and hydrogen production were the most commonly used keywords in the publications. The size of the circles is related to the number of the author keyword while the thickness of the lines between circles shows to the frequency of cooperation between two keywords.

Table 4. Top five highly cited papers based on Total Citation

\begin{tabular}{|l|l|l|l|l|l|l|}
\hline Authors & Year & CC & TA & TC/Y & TC & Journal \\
\hline Rönsch et al. [98] & 2016 & Germany & 8 & 117.2 & 586 & Fuel \\
\hline Acar and Dincer [99] & 2014 & Canada & 2 & 47.57 & 333 & Int. J. of Hydrogen Energy \\
\hline Beer [100] & 2007 & USA & 1 & 22.13 & 332 & Prog. in Energy and Comb. Sci. \\
\hline Siriwardane et al. [1] & 2005 & USA & 3 & 20.62 & 330 & Energy\&Fuels \\
\hline Irfan et al. [101] & 2011 & Malaysia & 3 & 32.3 & 323 & Energy\&Fuels \\
\hline
\end{tabular}

Note: CC is the corresponding author's country; TA is the number of co-authors; TC/Y is the total citation per year; TC is the number of the total citation.

Table 4 shows the top five frequently cited articles in the field of coal gasification between 1989 and 2020 . The most frequently cited article entitled "Review on methanation - From fundamentals to current projects" was authored by Stefan Rönsch, Jens Schneider, Steffi Matthischke, Michael Schlueter, Manuel Götz, Jonathan Lefebvre, Praseeth Prabhakaran, Siegfried Bajohr and published in Fuel in 2016. It has been cited 586 times by the year 2020 . 


\section{CONCLUSION}

Energy demand increases day by day. Therefore, it is very important to use energy sources efficiently. Coal is one of the most used energy sources. A way of using coal efficiently is the gasification of coal. The scientific publications on coal gasification at the Web of Science database were examined in terms of bibliometric properties and relations between different structures. Then the results were visualized through social network analysis. The major results from this study are summarized as follows;

- Using a bibliometric analysis technique, the number of publications of a country, the number of publications of an institute and the quality of those publications can be determined in a scientific field.

- In total, 3413 publication have been found in the subject of coal gasification according to the selected research areas such as thermodynamics, engineering, energy fuels and chemistry between 1989 and 2020.

- The number of coal gasification publications have increased between 1989 and 2020 especially after 2005. The result shows that the topic presents a rising trend.

- Despite the fact that China is the top country in terms of productivity, the developed countries such as USA, Japan, Canada, Poland, South Korea and Germany are in the upper ranks at the most productive countries list. Turkey has a leading position among the Middle East countries.

- The most productive author is Han HJ from China. The most frequently cited article authors are Stefan Rönsch, Jens Schneider, Steffi Matthischke, Michael Schlueter, Manuel Götz, Jonathan Lefebvre, Praseeth Prabhakaran and those authors published in the journal of "Fuel" in 2016.

- "Fuel", "Energy and Fuel" and "International Journal of Hydrogen Energy" were found as the most preferred journals by the authors. "Fuel" that has an impact factor of 5.578 and an h-index of 56 accounts for $9.69 \%$ of the total coal gasification publications between 1989 and 2020. "Fuel" is a journal with a large influence on coal gasification research. The journal has published 10.6 papers on an average per year related to the coal gasification.

- According to the publication types, the rate of the articles is $77.09 \%$, the rate of conference proceeding paper is $24.40 \%$ and the rate of the review is $3.281 \%$.

- The most used language in publications is in English (97.01\%) followed by Polish (1.11\%), Japanese $(0.76 \%)$, German $(0.73 \%)$, and Chinese $(0.11 \%)$.

- The data of each database cannot be evaluated without any action. For that reason, serious data cleaning must be done on the database.

\section{CONFLICTS OF INTEREST}

No conflict of interest was declared by the authors.

\section{REFERENCES}

[1] Siriwardane, R.V., Shen, M.S., Fisher, E.P., Losch, J., "Adsorption of CO2 on Zeolites at Moderate Temperatures", Energy \& Fuels, 19: 1153-9, (2005).

[2] Self, S.J., Reddy, B.V., Rosen, M.A., "Review of underground coal gasification technologies and carbon capture", International Journal of Energy and Environmental Engineering, 3: 16, (2012).

[3] Al-Zareer, M., Dincer, I., Rosen, M.A., "Analysis and assessment of a hydrogen production plant consisting of coal gasification, thermochemical water decomposition and hydrogen compression systems", Energy Conversion and Management, 157: 600-18, (2018).

[4] Al-Zareer, M., Dincer, I., Rosen, M.A., "Development of an integrated system for electricity and hydrogen production from coal and water utilizing a novel chemical hydrogen storage technology", Fuel Processing Technology, 167: 608-21, (2017). 
[5] Seyitoglu, S.S., Dincer, I., Kilicarslan, A., "Energy and exergy analyses of hydrogen production by coal gasification", International Journal of Hydrogen Energy, 42: 2592-600, (2017).

[6] Seyitoglu, S.S., Dincer, I., Kilicarslan, A., "Assessment of an IGCC based trigeneration system for power, hydrogen and synthesis fuel production", International Journal of Hydrogen Energy, 41: 8168-75, (2016).

[7] Mondol, J.D., McIlveen-Wright, D., Rezvani, S., Huang, Y., Hewitt, N., "Techno-economic evaluation of advanced IGCC lignite coal fuelled power plants with CO2 capture", Fuel, 88: 2495506, (2009).

[8] Salkuyeh, Y.K., Adams, T.A., "Combining coal gasification, natural gas reforming, and external carbonless heat for efficient production of gasoline and diesel with $\mathrm{CO} 2$ capture and sequestration", Energy Conversion and Management, 74: 492-504, (2013).

[9] Nag, P., Raha, D., "Thermodynamic Analysis of a Coal-based Combined cycle power plant", Heat Recover Systems, 15: 115-29, (1995).

[10] Joshi, M.M., Lee, S., "Integrated Gasification Combined Cycle- A Review of IGCC Technology", Energy Sources, 18: 537-68, (1996).

[11] Bhattacharyya, D., Turton, R., Zitney, S.E., "Steady-State Simulation and Optimization of an Integrated Gasification Combined Cycle Power Plant with CO2 Capture", Industrial \& Engineering Chemistry Research, 50: 1674-90, (2011).

[12] Duan, W., Yu, Q., Xie, H., Liu, J., Wang, K., Qin, Q., Han, Z., "Thermodynamic analysis of synergistic coal gasification using blast furnace slag as heat carrier", International Journal of Hydrogen Energy, 41: 1502-12, (2016).

[13] Kaneko, S., "Integrated Coal Gasification Combined Cycle: A Reality, Not a Dream", Journal of Energy Engineering, 142: E4015018, (2016).

[14] Sudiro, M., Bertucco, A., "Production of synthetic gasoline and diesel fuel by alternative processes using natural gas and coal: Process simulation and optimization", Energy, 34: 2206-14, (2009).

[15] Duan, L., Sun, S., Yue, L., Qu, W., Yang, Y., "Study on a new IGCC (Integrated Gasification Combined Cycle) system with CO2 capture by integrating MCFC (Molten Carbonate Fuel Cell)", Energy, 87: 490-503, (2015).

[16] Huang, J., Dincer, I., "Parametric analysis and assessment of a coal gasification plant for hydrogen production", International Journal of Hydrogen Energy, 39: 3294-303, (2014).

[17] Emun, F., Gadalla, M., Majozi, T., Boer, D., "Integrated gasification combined cycle (IGCC) process simulation and optimization", Computers \& Chemical Engineering, 34: 331-8, (2010).

[18] Li, Y., Guo, L., Zhang, X., Jin, H., Lu, Y., "Hydrogen production from coal gasification in supercritical water with a continuous flowing system", Intertational Journal of Hydrogen Energy, 35: 3036-45, (2010).

[19] Wall, T.F., Liu, G., Wu, H., Roberts, D.G., Benfell, K.E., Gupta, S., "The effects of pressure on coal reactions during pulverised coal combustion and gasification", Progress in Energy and Combustion Science, 28: 405-33, (2002).

[20] Giuffrida, A., Romano, M.C., Lozza, G., "Thermodynamic analysis of air-blown gasification for IGCC applications", Applied Energy, 88: 3949-58, (2011). 
[21] Chen, Z., Zhang, X., Han, W., Gao, L., Li, S., "Exergy analysis on the process with integrated supercritical water gasification of coal and syngas separation", Applied Thermal Engineering, 128: 1003-8, (2018).

[22] Fermoso, J., Arias, B., Plaza, M.G., Pevida, C., Rubiera, F., Pis, J.J., "High-pressure co-gasification of coal with biomass and petroleum coke", Fuel Processing Technology, 90: 926-32, (2009).

[23] Kumar, S., "Clean Hydrogen Production Methods", Volume 2, Springer International Publishing, (2015).

[24] Basu, P., "Biomass Gasification and Pyrolysis Handbook", Elsevier, (2010).

[25] Higman, C., Van Der Burgt, M., "Gasification", Second Edition, Elsevier, (2008).

[26] Abani, N., Ghoniem, A.F., "Large eddy simulations of coal gasification in an entrained flow gasifier", Fuel, 104: 664-80, (2013).

[27] Dincer, I., Acar, C., "Review and evaluation of hydrogen production methods for better sustainability", International Journal of Hydrogen Energy, 40: 11094-111, (2015).

[28] Dincer, I., Rosen, M.A., "Sustainability aspects of hydrogen and fuel cell systems", Energy for Sustainable Development, 15: 137-46, (2011).

[29] Wang, Y., Wang, J., Luo, X., Guo, S., Lv, J., Gao, Q., "Dynamic modelling and simulation of IGCC process with Texaco gasifier using different coal", Systems Science \& Control Engineering, 3: 198210, (2015).

[30] Botros, B.B., Brisson, J.G., "Integrated gasification combined cycle (IGCC) process simulation and optimization", International Journal of Heat and Mass Transfer, 61: 129-37, (2013).

[31] Ng, Y.C., Lipiński, W., "Thermodynamic analyses of solar thermal gasification of coal for hybrid solar-fossil power and fuel production", Energy, 44: 720-31, (2012).

[32] Li, F., Fan, H., Fang, Y., "Exploration of Slagging Behaviors during Multistage Conversion Fluidized-Bed (MFB) Gasification of Low-Rank Coals", Energy \& Fuels, 29: 7816-24, (2015).

[33] Jones, D., Bhattacharyya, D., Turton, R., Zitney, S.E., "Optimal design and integration of an air separation unit (ASU) for an integrated gasification combined cycle (IGCC) power plant with $\mathrm{CO} 2$ capture", Fuel Processing Technology, 92: 1685-95, (2011).

[34] Mondal, P., Dang, G.S., Garg, M.O., "Syngas production through gasification and cleanup for downstream applications — Recent developments", Fuel Processing Technology, 92: 1395-410, (2011).

[35] Gazzani, M., Macchi, E., Manzolini, G., "CO2 capture in natural gas combined cycle with SEWGS. Part A: Thermodynamic performances", International Journal of Greenhouse Gas Control, 12: 493501, (2013).

[36] Wender, I., "Reactions of synthesis gas", Fuel Processing Technology, 48: 189-297, (1996).

[37] Steibel, M., Halama, S., Geißler, A., Spliethoff, H., "Gasification kinetics of a bituminous coal at elevated pressures: Entrained flow experiments and numerical simulations", Fuel, 196: 210-6, (2017). 
[38] Seo, H.K., Park, S., Lee, J., Kim, M., Chung, S.W., Chung, J.H., "Effects of operating factors in the coal gasification reaction", Korean Journal of Chemical Engineering, 28: 1851-8, (2011).

[39] Lang, Y., Zitney, S.E., Biegler, L.T., "Optimization of IGCC processes with reduced order CFD models", Computers and Chemical Engineering, 35: 1705-17, (2011).

[40] Chen, C., Horio, M., Kojima, T., "Numerical simulation of entrained flow coal gasifiers. Part I: modeling of coal gasification in an entrained flow gasifier", Chemical Engineering Science, 55: 3861-74, (2000).

[41] Ratafia-Brown, J.A., Manfredo, L.M., Hoffmann, J.W., Ramezan, M., Stiegel, G.J., "An environmental assessment of igcc power systems", Nineteenth Annual Pittsburgh coal Conference, Pittsburgh, Pa, USA, (2002).

[42] Kim, M., Ye, I., Ryu, C., "Numerical analysis on transient behaviors of slag layer in an entrainedflow coal gasifier", Fuel, 196: 532-42, (2017).

[43] Wang, L., Jia, Y.J., Kumar, S., Li, R., Mahar, R.B., Ali, M., "Numerical analysis on the influential factors of coal gasification performance in two-stage entrained flow gasifier", Applied Thermal Engineering, 112: 1601-11, (2017).

[44] Zhu, L., Zhang, Z., Fan, J., Jiang, P., "Polygeneration of hydrogen and power based on coal gasification integrated with a dual chemical looping process: Thermodynamic investigation", Computer and Chemical Engineering, 84: 302-12, (2016).

[45] Liszka, M., Malik, T., Manfrida, G., "Energy and exergy analysis of hydrogen-oriented coal gasification with CO2capture", Energy, 45: 142-50, (2012).

[46] Lin, S., Harada, M., Suzuki, Y., Hatano, H., "Hydrogen production from coal by separating carbon dioxide during gasification", Fuel, 81: 2079-85, (2002).

[47] Aghahosseini, S., Dincer, I., Naterer, G.F., "Integrated gasification and Cu-Cl cycle for trigeneration of hydrogen, steam and electricity", International Journal of Hydrogen Energy, 36: 2845-54, (2011).

[48] Jordal, K., Anantharaman, R., Peters, T.A., Berstad, D., Morud, J., Nekså, P., "High-purity H2production with CO2capture based on coal gasification", Energy, 88: 9-17, (2015).

[49] Gnanapragasam, N.V., Reddy, B.V., Rosen, M.A., "Hydrogen production from coal gasification for effective downstream CO2 capture", International Journal of Hydrogen Energy, 35: 4933-43, (2010).

[50] Ozturk, M., Dincer, I., "Thermodynamic assessment of an integrated solar power tower and coal gasification system for multi-generation purposes", Energy Conversion and Management, 76: 106172, (2013).

[51] Gootz, M., Forman, C., Meyer, B., "Polygeneration-Annex: Integrating hydrogen into syngas-based gasoline production", International Journal of Hydrogen Energy, 42: 24067-78, (2017).

[52] Huang, Y., Chu, Q., Yi, Q., Li, W., Xie, K., Sun, Q., "Feasibility analysis of high-low temperature Fischer-Tropsch synthesis integration in olefin production", Chemical Engineering Research and Design, 131: 92-103, (2018). 
[53] Wu, Y., Feng, J., Li, W., "System development of integrated high temperature and low temperature Fischer-Tropsch synthesis for high value chemicals", Chemical Engineering Research and Desisgn, 131: 80-91, (2018).

[54] Cormos, A., Dinca, C., Cormos, C.C., "Multi-fuel multi-product operation of IGCC power plants with carbon capture and storage (CCS)", Applied Thermal Engineering, 74: 20-7, (2015).

[55] Chen, Y., "Optimal design and operation of energy polygeneration system", Journal of Process Control, 30: 319, (2013).

[56] Adams, T.A., Barton, P.I., "Combining coal gasification, natural gas reforming, and solid oxide fuel cells for efficient polygeneration with CO2 capture and sequestration", Fuel Processing Technology, 92: 2105-15, (2011).

[57] Yu, G., Xu, Y., Hao, X., Li, Y., Liu, G., "Process analysis for polygeneration of Fischer-Tropsch liquids and power with CO2 capture based on coal gasification", Fuel, 89: 1070-6, (2010).

[58] Pritchard, A., "Statistical Bibliography or Bibliometrics", Journal of Documentation, 25: 348-9, (1969).

[59] Subramanyam, K., "Bibliometric studies of research collaboration: A review", Information Scientist, 6: 33-8, (1983).

[60] McBurney, M.K., Novak, P.L., "What is bibliometrics and why should you care?", Proceedings. IEEE International Professional Communication Conference, IEEE, 108-14, (2002).

[61] Wang, M.H., Yu, T.C., Ho, Y.S., "A bibliometric analysis of the performance of Water Research", Scientometrics, 84: 813-20, (2010).

[62] Ma, X., Gao, M., Gao, Z., Wang, J., Zhang, M., Ma, Y., "Past, current, and future research on microalga-derived biodiesel: a critical review and bibliometric analysis", Environmental Science of Pollution Research, 25: 10596-610, (2018).

[63] Zhang, M., Gao, Z., Zheng, T., Ma, Y., Wang, Q., Gao, M., "A bibliometric analysis of biodiesel research during 1991-2015", Journal of Material Cycles ad Waste Management, 20: 10-8, (2018).

[64] Li, N., Han, R., Lu, X., "Bibliometric analysis of research trends on solid waste reuse and recycling during 1992-2016", Resources, Conservation and Recycling, 130: 109-17, (2018).

[65] Tian, X., Geng, Y., Zhong, S., Wilson, J., Gao, C., Chen, W., "A bibliometric analysis on trends and characters of carbon emissions from transport sector", Transportation Research Part D: Transport and Environment, 59: 1-10, (2018).

[66] Park, J.Y., Nagy, Z., "Comprehensive analysis of the relationship between thermal comfort and building control research - A data-driven literature review", Renewable and Sustainable Energy Reviews, 82: 2664-79, (2018).

[67] Imran, M., Haglind, F., Asim, M., Zeb Alvi, J., "Recent research trends in organic Rankine cycle technology: A bibliometric approach", Renewable and Sustainable Energy Reviews, 81: 552-62, (2018).

[68] Chen, W., Liu, W., Geng, Y., Brown, M.T., Gao, C., Wu, R., "Recent progress on emergy research: A bibliometric analysis", Renewable and Sustainable Energy Reviews, 73: 1051-60, (2017). 
[69] Wang, Q., Li, R., "Research status of shale gas: A review", Renewable and Sustainable Energy Reviews, 74: 715-20, (2017).

[70] Zhang, Y., Huang, K., Yu, Y., Yang, B., "Mapping of water footprint research: A bibliometric analysis during 2006-2015", Journal of Cleaner Production, 149: 70-9, (2017).

[71] Wang, L., Zhao, L., Mao, G., Zuo, J., Du, H., "Way to accomplish low carbon development transformation: A bibliometric analysis during 1995-2014", Renewable and Sustainable Energy Reviews, 68: 57-69, (2017).

[72] Geng, Y., Chen, W., Liu, Z., Chiu, A.S.F., Han, W., Liu, Z., "A bibliometric review: Energy consumption and greenhouse gas emissions in the residential sector", Journal of Cleaner Production, 159: 301-16, (2017).

[73] Feng, Y., Zhu, Q., Lai, K.H., "Corporate social responsibility for supply chain management: A literature review and bibliometric analysis", Journal of Cleaner Production, 158: 296-307, (2017).

[74] Zeng, R., Chini, A., "A review of research on embodied energy of buildings using bibliometric analysis", Energy and Buildings, 155: 172-84, (2017).

[75] Lora Grando, R., de Souza Antune, A.M., da Fonseca, F.V., Sánchez, A., Barrena, R., Font, X., "Technology overview of biogas production in anaerobic digestion plants: A European evaluation of research and development", Renewable and Sustainable Energy Reviews, 80: 44-53, (2017).

[76] Jiang, H., Qiang, M., Lin, P., "A topic modeling based bibliometric exploration of hydropower research", Renewable and Sustainable Energy Reviews, 57: 226-37, (2016).

[77] Chen, H.Q., Wang, X., He, L., Chen, P., Wan, Y., Yang, L., "Chinese energy and fuels research priorities and trend: A bibliometric analysis", Renewable and Sustainable Energy Reviews, 58: 966-75, (2016).

[78] Zhang, K., Liang, Q-M., "Recent progress of cooperation on climate mitigation: A bibliometric analysis", Journal of Cleaner Production, 277: 123495, (2020).

[79] Li, Z., Chen, Z., Yang, N., Wei, K., Ling, Z., Liu, Q., "Trends in research on the carbon footprint of higher education: A bibliometric analysis (2010-2019)", Journal of Cleaner Production, 289: 125642, (2021).

[80] Kasavan, S., Yusoff, S., Rahmat Fakri, M.F., Siron, R., "Plastic pollution in water ecosystems: A bibliometric analysis from 2000 to 2020", Journal of Cleaner Production, 313: 127946, (2021).

[81] Bailón-Moreno, R., Jurado-Alameda, E., Ruiz-Baños, R., Courtial, J.P., "Bibliometric laws: Empirical flaws of fit", Scientometrics, 63: 209-29, (2005).

[82] Wang, Y., Lai, N., Zuo, J., Chen, G., Du, H., "Characteristics and trends of research on waste-toenergy incineration: A bibliometric analysis, 1999-2015", Renewable and Sustainable Energy Reviews, 66: 95-104, (2016).

[83] Fairthorne, R.A., "Empirical hyperbolic distributions (Bradford-Zipf-Mandelbrot) for bibliometric description and prediction", Journal of Documentations, 61: 171-93, (2005).

[84] Tsay, M.Y., Jou, S.J., Ma, S.S., "A bibliometric study of semiconductor literature, 1978-1997", Scientometrics, 49: 491-509, (2000). 
[85] Callon, M., Courtial, J.P., Laville, F., "Co-word analysis as a tool for describing the network of interactions between basic and technological research: The case of polymer chemsitry", Scientometrics, 22: 155-205, (1991).

[86] Small, H., "Tracking and predicting growth areas in science", Scientometrics, 68: 595-610, (2006).

[87] Prasara-A, J., Gheewala, S.H., "Sustainable utilization of rice husk ash from power plants: A review", Journal of Cleaner Production, 167: 1020-8, (2018).

[88] Cobo, M.J., López-Herrera, A.G., Herrera-Viedma, E., Herrera, F., "Science mapping software tools: Review, analysis, and cooperative study among tools", Journal of the American Society for Information Science and Technology, 62: 1382-402, (2011).

[89] Fahimnia, B., Tang, C.S., Davarzani, H., Sarkis, J., "Quantitative models for managing supply chain risks: A review", European Journal of Operational Research, 247: 1-15, (2015).

[90] Belter, C.W., "Bibliometric indicators: opportunities and limits", Journal of the Medical Library Association, 103: 219-21, (2015).

[91] Persson, O., Danell, R., Schneider, J.W., "How to use Bibexcel for various types of bibliometric analysis", Celebrating scholarly communication studies: A Festschrift for Olle Persson at his 60th Birthday, 9-24, (2009).

[92] de Paulo, A.F., Porto, G.S., "Solar energy technologies and open innovation: A study based on bibliometric and social network analysis", Energy Policy, 108: 228-38, (2017).

[93] Ivanović, D., Fu, H.Z., Ho, Y.S., "Publications from Serbia in the Science Citation Index Expanded: a bibliometric analysis", Scientometrics, 105: 145-60, (2015).

[94] Wong, S., Mah, A.X.Y., Nordin, A.H., Nyakuma, B.B., Ngadi, N., Mat, R., "Emerging trends in municipal solid waste incineration ashes research: a bibliometric analysis from 1994 to 2018", Environmental Science and Pollution Research, 27: 84, (2020).

[95] Huang, L., Chen, K., Zhou, M., "Climate change and carbon sink: a bibliometric analysis", Environmental Science and Pollution Research, 27: 8740-58, (2020).

[96] Pérez-Fortes, M., Bojarski, A.D., Velo, E., Nougués, J.M., Puigjaner, L., "Conceptual model and evaluation of generated power and emissions in an IGCC plant", Energy, 34: 1721-32, (2009).

[97] Liu, H., Ni, W., Li, Z., Ma, L., "Strategic thinking on IGCC development in China", Energy Policy, 36: $1-11,(2008)$.

[98] Rönsch, S., Schneider, J., Matthischke, S., Schlüter, M., Götz, M., Lefebvre, J., "Review on methanation - From fundamentals to current projects", Fuel, 166: 276-96, (2016).

[99] Acar, C., Dincer, I., "Comparative assessment of hydrogen production methods from renewable and non-renewable sources", International Journal of Hydrogen Energy, 39: 1-12, (2014).

[100] Beér, J.M., "High efficiency electric power generation: The environmental role", Progress in Energy Combustion Science, 33: 107-34, (2007).

[101] Irfan, M.F., Usman, M.R., Kusakabe, K., "Coal gasification in $\mathrm{CO} 2$ atmosphere and its kinetics since 1948: A brief review", Energy, 36: 12-40, (2011). 